\title{
THE WORD OF 'BASAR’ AND ITS MERONYM IN QURAN: COMPARATIVE STUDY BETWEEN QURANIC DICTIONARIES
}

\author{
Mohamed Akhiruddin Ibrahim ${ }^{1^{*}}$, Hishomudin Ahmad ${ }^{2}$, Robiatul Adawiyah Mohd ${ }^{3}$, \\ Muhammad Widus Sempo ${ }^{4}$ and Nur Farhana Baharuddin ${ }^{5}$ \\ ${ }^{1}$ Dr., Senior Lecturer, Faculty of Quranic and Sunnah Studies, Universiti Sains Islam Malaysia, \\ Nilai, Negeri Sembilan, MALAYSIA, akhiruddin@usim.edu.my \\ ${ }^{2}$ Dr., Senior Lecturer, Faculty of Major Languages, Universiti Sains Islam Malaysia, Nilai, Negeri \\ Sembilan, MALAYSIA. \\ ${ }^{3}$ Dr., Senior Lecturer, Faculty of Quranic and Sunnah Studies, Universiti Sains Islam Malaysia, \\ Nilai, Negeri Sembilan, MALAYSIA. \\ ${ }^{4}$ Dr., Senior Lecturer, Islamic Science Institute, Universiti Sains Islam Malaysia, Nilai, Negeri \\ Sembilan, MALAYSIA. \\ ${ }^{5}$ Student, Faculty of Quranic and Sunnah Studies, Universiti Sains Islam Malaysia, Nilai, Negeri \\ Sembilan, MALAYSIA. \\ ${ }^{*}$ Corresponding author
}

\begin{abstract}
The knowledge on the meaning of Quranic individual words is one of the essential prerequisite in order to comprehend the verses of Quran. A specific semantic relation to linguistics namely as meronym, represents a structural sense relation between meanings that become a fundamental part of, and refers to a bundle of different part-to-whole relationships of a word. The understanding of meronym relations, are at the heart of many question-answering systems and define the root meaning of the word itself. Therefore, this study aims to discuss the meaning of the word Basar and its meronym in Quran based on a comparison between four Quran dictionaries which are Quran Corpus, Al-Mu'jam Al-Mufahras li Alfaz Al-Quran, Qaimah Mu'jamiyah bi Alfaz Al-Quran Al-Karim wa Darajat Tikrariha and Mu'jam Alfaz Al-Qur'an Al Karim. The study applied document analysis by identifying the meronym of word basar in Quran. Then the data was analysed and compared between those aformentioned dictionaries. The findings obtained shows that 'Ayn is the meronym of the word Basar that means eye. The study also found that there are similarities and differences regarding the frequency of word Basar and 'Ayn between these sources. A comparative study of these words in Quran would therefore be of great interest, and the further discussions are expected to explain the comparison of the word Basar and 'Ayn in Quran based on other Quran linguistic sources.
\end{abstract}

Keywords: Basar, Quran, Meronym, Comparative

\section{INTRODUCTION}

The two primary sources of Islam consist of Quran and Sunnah came with Arabic language. Allah says in His verse: "Indeed, We have made it an Arabic that you might understand" (Surah al-Zukhruf: 3). Therefore, a 
good understanding of Arabic language is a requirement to learn and understand the meanings indicated by the Quran and Sunnah with respect to Islamic Law (Hamidah Mat \& Wan Mohamad Ubaidillah, 2016). Quran language is different from any other classical Arabic text in term of its eloquence and style. It is also rich in its vocabulary, morphology and syntactic structures. Within the same verses, some words of Quran bring their own contextual meanings. For instance, the word fitnah in the Quran came out with eleven different meanings in different contexts (Maha Alrabia et al., 2014). Allah has chosen each word in the Quran for a purpose as it is part of its miracle. There is a lot of things have been mentioned in Quran that have their own specific meaning and function. This feature and some more make the Quran as the most challenging Arabic text to be understood and man need to study the meanings of the words through analysis of their distributional semantics in contemporaneous texts (Muhammad Luqman et al., 2017).

Semantic plays an important role of Arabic language processing with a composite morphology that are categorized as nouns, particles and verbs (Ahmad T. Al-Taani and Alaa M. Al-Gharaibeh, 2010). The important of linguistic features for the Arabic linguists can be considered as synonym, antonym, hypernym, hyponym, meronym, holonym and association relations in Arabic language (Hossam Ishkewy et al., 2014). In this study, the researchers will discuss about meronym that will be focus on the Arabic word Basar in Quran. Meronymy means a structural sense relation between meanings while part-whole is a relation between two physical entities (Misbah M. D. Al-Sulaimaan \& Amal Y. Muhammed, 2006). It also can be defined as a noun phrase that represents a part of a whole (Mitra Bokaei Hosseini et al., 2016). Meanwhile, Basar according to almaany dictionary means eyesight, seeing, sight and vision (almaany, n.d). In Wikipedia, Basar is elaborated as the visual perception, eyesight, sight, or vision resulting from the ability to interpret the surrounding environment using light in the visible spectrum reflected by the objects in the environment (Wikipedia1, n.d). It is mentioned a lot in the Quranic verses such as in surah al-Mulk, Allah says: "So return [your] vision [to the sky]; do you see any breaks?" Hence, this study will reveal the word Basar in Quran and its meronym referring to four different Quranic dictionaries.

As mentioned above, the four different dictionaries are Quran Corpus, Mu'jam Mufahras Li Alfaz Al-Quran, Qaimah Mu'jamiyah bi Alfaz Al-Quran Al-Karim wa Darajat Tikrariha and Mujam Alfaz Al-Qur'an Al Karim. Quran Corpus was created by Kais and his colleagues from University of Leeds aims to produce a new linguistic resource rich in morphological information that enables people to do more analysis of the Quran and generally contribute to the research in Arabic Natural Language Processing community (Zeroual Imad \& Lakhouaja Abdelhak, 2014). It is also an online annotated linguistic resource consists of 77,430 words of Quranic Arabic that shows the Arabic grammar, syntax and morphology for each word in the Quran. (Kais Dukes \& Nizar Habash, 2010). Mu'jam al-Mufahras Li Alfaz al-Quran is the second resource in this study compiled by Muhammad Fuad Abdul Baqi. It is a reference that collecting Quranic verses based on the root of word according to its alphabetical order (alif - ya). It comes with number and name of the Surah (Al-Baqi, 1364H).Thirdly, Qaimah Mu'jamiyah bi Alfaz Al-Quran Al-Karim wa Darajat Tikrariha by Muhammad Husayn Abu al-Futuh is the Quranic dictionary that arranged in alphabetical order, taking into consideration the form of the word at the same time focuses on the word of Quran and its frequency (Abu al-Futuh, 1990). Meanwhile, Fourthly, Mu'jam Alfaz Al-Qur'an Al Karim by Arabic Language Academy is a dictionary that organized into alphabetical order with the description of meaning and Quranic verses included the name and number of Surah (Arabic Language Academy, 1988). These four dictionaries will be compared by researchers in term of similarities and differences of the word Basar and its meronym.

\section{METHODOLOGY}

A methodology means a set of methods that define the process and order of how something is to be achieved (Andrew \& Ainslie, 2000). This study applied qualitative approach by using document analysis. It involved four steps as follow:

1. Identifying meronym for the Arabic word "basar"

2. Analyzing words of "basar" and it meronym which is "ayn" in al-Quran.

3. Morphological analysis was applied to explore distribution of word types (noun, verb, active participle, passive participle and verbal noun).

4. Analyzing the words that have the same root but in different forms and types in a sentence or several sentences. The similarities and differences between the frequency of words and the form of words according to Arabic grammar between the four Quranic dictionaries were analyzed to produce comparative results.

\section{RESULTS}

This part will discuss about the word Basar and its meronym in Quran according to Quran Corpus, Mu'jam 
Mufahras Li Alfaz Al-Quran, Qaimah Mu'jamiyah bi Alfaz Al-Quran Al-Karim wa Darajat Tikrariha and Mujam Alfaz Al-Qur'an Al Karim. The study shows that the meaning of Basar is eyesight, sight, or vision and the part of Basar is 'Ayn which means eye according to almaany. Eye is a sense organ which reacts to light and pressure that allows vision (Wikipedia2, n.d). The researchers aim to compare between the word Basar and 'Ayn in the Quran based on four dictionaries.

\subsection{Basar in Quran Corpus, Al-Mu'jam Al-Mufahras li Alfaz Al-Quran, Qaimah Mu'jamiyah bi Alfaz Al-Quran Al-Karim wa Darajat Tikrariha and Mujam Alfaz Al-Qur'an Al Karim}

According to figure 1.0 below, the study reveals that the total of the word Basar in Quran according to Mu'jam Alfaz Al-Qur'an Al Karim is the lowest which is 145 times while the other dictionaries is the same in total that is 148 times. Regarding to the figure, QC refers to Quran Corpus, MM refers to Al-Mu'jam AlMufahras li Alfaz Al-Quran, QM refers to Qaimah Mu'jamiyah bi Alfaz Al-Quran Al-Karim wa Darajat Tikrariha and MA means Mujam Alfaz Al-Qur'an Al Karim.

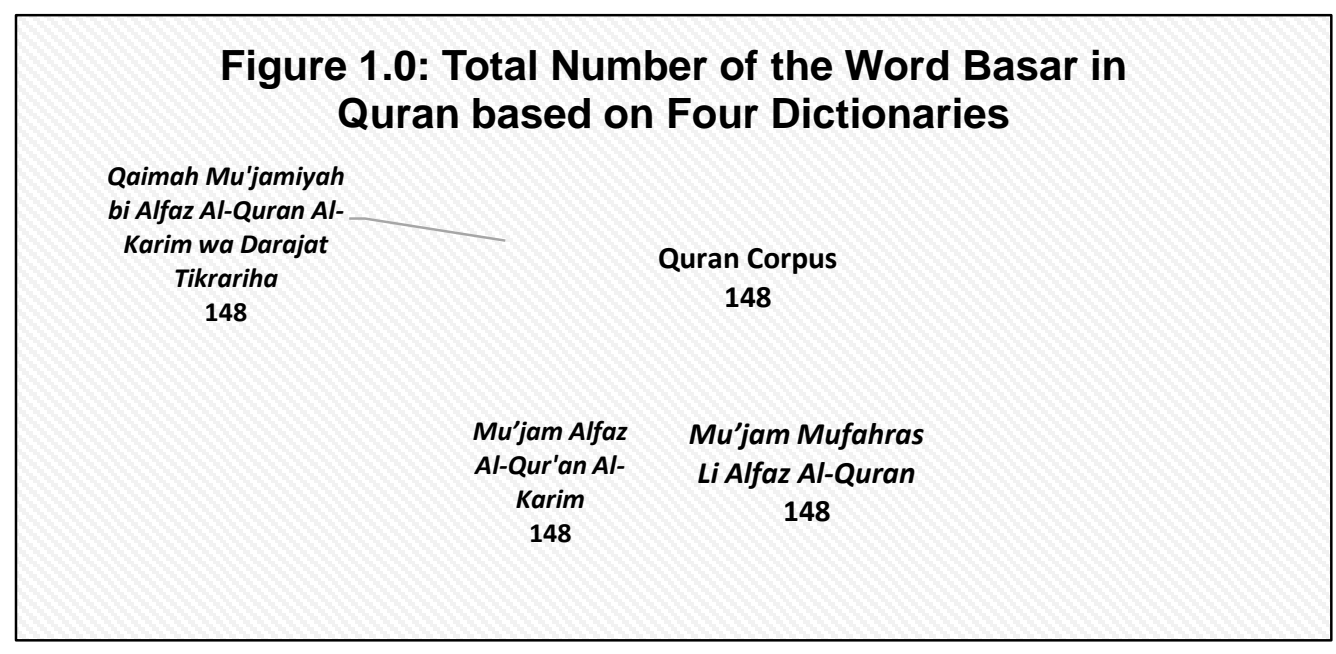

\section{Sources: The Quranic Arabic Corpus (n.d), Al-Baqi (1364H), Abu al-Futuh (1990) \& Arabic Language Academy (1988)}

\subsubsection{Quran Corpus}

Acording to this dictionary, Basar with the root bā șād rā occurs 148 times in the Quran consists of four forms include verb (fi'i), noun (isim), active participle (isim al-fi'il) and verbal noun (al-masdar). Verb is an action word in relation to time that is past (fi'il al-mādhi), present (fi'il al-mudhāri') and imperative (fi'il amar) (Zahoor Ahmed, 2008). Verbs of Basar in Quran Corpus involves all tenses such as bașurat (past tense), abșara (present tense) and absir (imperative tense). There are also noun which is bașir means All-Seer. The noun consists of singular (mufrad) and plural (jama'). A few of active participle for the word Basar in Quran such as mubșiran means giving visibility and mub'șiratan that is visible. Besides, the verbal noun includes tabșiratan means giving insight. It is the source from which all the nouns and verbs are derived (Izzath Uroosa, 2010). There are nominal sentences (al-Jumlah al-Ismiyah) consists of the subject (al-mubtada') and the predicate (al-Khabar) such as the word bașirun in the verse inna Allaha bima ta'malun basiir (Zahoor Ahmed, 2008).

\subsubsection{Mu'jam Mufahras Li Alfaz Al-Quran}

There are 148 times of word with root bā șād rā. All tenses of verb for the word Basar contained in this dictionary. In addition, several noun are identified consists of singular such as bașarihi and plural such as alabșāru. The example of verbal noun is tabșiratan while for nominal is the word bașiran and mub'șiran for active participle.

\subsubsection{Qaimah Mu'jamiyah bi Alfaz Al-Quran Al-Karim wa Darajat Tikrariha}

The word Basar repeats 148 times in this dictionary. It is found that the total of the word Basir is the most in Quran which is 53 times. The verb can be found in all tenses while noun exists in singular and plural. In addition, the word Basar also available in verbal noun, nominal and active participle.

\subsubsection{Mu'jam Alfaz Al-Qur'an Al-Karim}

The word Basar in this dictionary occurs 145 times in the form of verbs with all tenses that are past tense 
such as basurtu, present tense which is yubsirun and imperative that is absir. There are also noun in singular and plural, verbal noun, nominal and active participle.

\section{2 'Ayn in Quran Corpus, Al-Mu'jam Al-Mufahras li Alfaz Al-Quran, Qaimah Mu'jamiyah bi} Alfaz Al-Quran Al-Karim wa Darajat Tikrariha and Mujam Alfaz Al-Qur'an Al Karim

Figure 2.0 below shows that the total of word frequency for 'Ayn is the same for the four dictionaries which is 65 times.

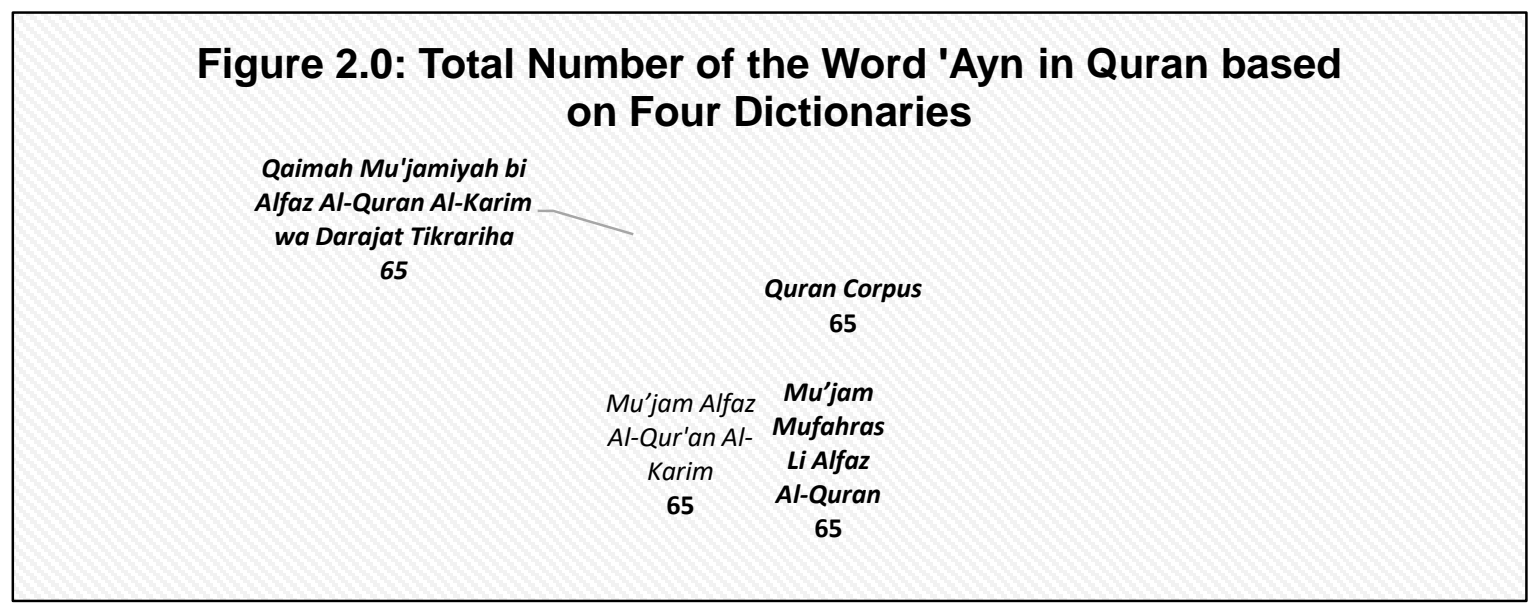

Sources: The Quranic Arabic Corpus (n.d), Al-Baqi (1364H), Abu al-Futuh (1990) \& Arabic Language Academy (1988)

\subsubsection{Quran Corpus}

The triliteral root 'ayn yā nūn repeats 65 times in the Quran, in two derived forms. Firstly, it is in the noun form which is 57 times includes singular, dual (mutsanna) and plural. In addition, it is also as the nominal 'in and ma'în. For example, the word 'inun in the verse wa 'indahum qaasiraatu al-tarfi 'aiyn.

\subsubsection{Mu'jam Mufahras Li Alfaz Al-Quran}

Based on this dictionary, there are also 65 times of the word 'Ayn in the Quran consists of noun and nominal. This word is not exist in the form of verb, verbal noun, active and passive participle. Noun is divided into singular such as al-'ayn, and the example for dual is 'aynāni and 'aynayni. Meanwhile, the examples for plural are a yuni and 'uyūnin.

\subsubsection{Qaimah Mu'jamiyah bi Alfaz Al-Quran Al-Karim wa Darajat Tikrariha}

There are number of 65 times of the word 'Ayn based on the root 'ayn yā nūn in Quran made up of noun which is 'ayn means eye for singular and plural for example 'uyūn and a'yun means the eyes. There are also nominal which are 'înun and ma iinin.

\subsubsection{Mu'jam Alfaz Al-Qur'an Al-Karim}

For this dictionary, there are about 65 times of the word 'Ayn in Quran consists of noun includes singular, dual and plural as well as nominal.

3.3 Similarities and differences between the word Basar and 'Ayn in Quran Corpus, AlMu'jam Al-Mufahras li Alfaz Al-Quran, Qaimah Mu'jamiyah bi Alfaz Al-Quran Al-Karim wa Darajat Tikrariha and Mujam Alfaz Al-Qur'an Al Karim

The result shows that the total of the word frequency for Basar in Quran is higher than the word 'Ayn. In general, there are 148 times for the word Basar while 65 times for 'Ayn. It is found that the word frequency are same for both words in these four dictionaries. However, it is clearly that the word Basar in Qaimah Mu'jamiyah bi Alfaz Al-Quran Al-Karim wa Darajat Tikrariha is less than others, which is 145 times. Regarding to the form of word, table 1.0 below explains the comparison between both dictionaries: 
Table 1.0: Forms of word Basar and 'Ayn in Quran based on Four Dictionaries

\begin{tabular}{|c|c|c|c|c|c|c|c|c|}
\hline & \multicolumn{3}{|c|}{ BASAR } & \multicolumn{5}{c|}{ 'AYN } \\
\hline DICTIONARY / FORM & QC & MA & QM & MM & QC & MA & QM & MM \\
\hline $\begin{array}{c}\text { VERB } \\
(\text { al-fi'il) }\end{array}$ & $\checkmark$ & $\checkmark$ & $\checkmark$ & $\checkmark$ & X & X & X & X \\
\hline $\begin{array}{c}\text { NOUN } \\
\text { (isim) }\end{array}$ & $\checkmark$ & $\checkmark$ & $\checkmark$ & $\checkmark$ & $\checkmark$ & $\checkmark$ & $\checkmark$ & $\checkmark$ \\
\hline $\begin{array}{c}\text { ACTIVE PARTICIPLE } \\
\text { (ismu al-fā'il) }\end{array}$ & $\checkmark$ & $\checkmark$ & $\checkmark$ & $\checkmark$ & $\mathrm{X}$ & $\mathrm{X}$ & $\mathrm{X}$ & $\mathrm{X}$ \\
\hline $\begin{array}{c}\text { PASSIVE PARTICIPLE } \\
\text { (ismu al-maf'ul) }\end{array}$ & $\checkmark$ & $\checkmark$ & $\checkmark$ & $\checkmark$ & $\mathrm{X}$ & $\mathrm{X}$ & $\mathrm{X}$ & $\mathrm{X}$ \\
\hline $\begin{array}{c}\text { VERBAL NOUN } \\
\text { (al-masdar) }\end{array}$ & $\checkmark$ & $\checkmark$ & $\checkmark$ & $\checkmark$ & $\mathrm{X}$ & $\mathrm{X}$ & $\mathrm{X}$ & $\mathrm{X}$ \\
\hline $\begin{array}{c}\text { NOMINAL } \\
\text { (al-Jumlah al-Ismiyah) }\end{array}$ & $\checkmark$ & $\checkmark$ & $\checkmark$ & $\checkmark$ & $\checkmark$ & $\checkmark$ & $\checkmark$ & $\checkmark$ \\
\hline
\end{tabular}

Sources: The Quranic Arabic Corpus (n.d), Al-Baqi (1364H), Abu al-Futuh (1990) \& Arabic Language Academy (1988)

In addition, based on Table 1.0, the word Basar and 'Ayn, can be found in the forms of noun and nominal in all these four Quranic dictionaries aforementioned. The result shows that the word 'Ayn is not available in the form of verb, active participle, passive participle and verbal noun. In term of noun, Basar can be seen in the form of singular and plural whereas the word 'Ayn consists of singular, dual and plural in Quran. However, the word 'Ayn cannot be found in form of dual in Qaimah Mu'jamiyah bi Alfaz Al-Quran Al-Karim wa Darajat Tikrariha. Regarding to the verb, the word Basar has all the three type of verb which are present tense, past tense and imperative in every dictionary.

\section{CONCLUSION}

In conclusion, meronym is a semantic relation specific to linguistics that denotes a constituent part or a member of something. It is a part of Arabic word groups like synonym, antonym, hypernym and hyponym. The study confirms that the word 'Ayn which means eye is the meronym for the word Basar. Through semantic study of these words in Quran Corpus, Al-Mu'jam Al-Mufahras li Alfaz Al-Quran, Qaimah Mu'jamiyah bi Alfaz Al-Quran Al-Karim wa Darajat Tikrariha and Mu'jam Alfaz Al-Qur'an Al Karim, it can be said that there are similarities and differences between these words in terms of frequency and form of word. Generally, the total of the word Basar in Quran is higher than 'Ayn based on these four dictionaries. The result also shows the similarities in the word frequency and form of word specifically noun and nominal. The different becomes apparent that the word 'Ayn only consists of noun and nominal in Quran while the word Basar can be divided broader into verb, noun, active participle, passive participle and verbal noun. Therefore, further discussions about the comparison of the word Basar and 'Ayn in Quran are expected to be done using the other Quran linguistic sources.

\section{ACKNOWLEDGEMENT}

Sincere gratitude and appreciation to those who contribute to this research. The researchers would like to acknowledge Research Management Centre Universiti Sains Islam Malaysia (USIM) for the management, Madam Shahirah Sulaiman for the language checks and Miss Siti Zulaikha Mokhtar for the article editing. This research is supported by the research grant with title: "A New Model to Understand the Content of Quran Using a Combination of Semantic Analysis and Socio-Linguistic Approaches for Diverse Group of People", research Code: USIM/TRGS02_PROJEK02/ISI/59/50516, by Ministry of Higher Education, Malaysia.

\section{REFERENCE LIST}

Abu al-Futuḥ, Muḥammad Ḥusayn (1990). Qaimah Mu'jamiyah bi Alfaz Al-Quran Al-Karim wa Darajat Tikrariha. Beirut: Maktabah Lubnan. 
IJASOS- International E-Journal of Advances in Social Sciences, Vol. IV, Issue 10, April 2018

Ahmad T. Al-Taani and Alaa M. Al-Gharaibeh (2010). Searching about Concept and Keywords in the Holy Quran. Master graduation project department of computer science. Yarmouk University.https://www.academia.edu/1205913/Searching_Concepts_and_Keywords_in_the_Holy_Qu ran

Al-Baqi, Muhammad Fuad 'Abd (1364H). Al-Mu'jam al-Mufahras Li Alfaz Al-Quran al-Karim. Dar al-Kutub alMisriyyah.

Almaany (n.d). عين. Retrieved from https://www.almaany.com/ar/dict/ar-ar/عين Accessed on 20 November 2017.

Andrew Hunter and Ainslie Ellis (2000). The Development Process for Courseware Material: A Computing Methodology Approach. Proceedings of the Seventeenth Annual Conference of the Australian Society for Computers in Learning In Tertiary Education. Australia: Monash University.

Arabic Language Academy (1988). Mu'jam Alfaz Al-Qur'an Al Karim. Cairo: Arabic Language Academy.

Hamidah Mat \& Wan Mohammad Ubaidillah Wan Abas (2016). The Relevance Of Arabic Language In Islamic Studies Program: A Case Study Of Open University Malaysia (OUM). Journal of Education and Social Sciences, Kuala Lumpur, 5 (2).

Hossam Ishkewy, Hany Harb \& Hassan Farahat (2014). Azhary: An Arabic Lexical Ontology. International Journal of Web \& Semantic Technology (IJWesT), 5(4). DOI: 10.5121/ijwest.2014.5405

Izzath Uroosa (2008). Learning Arabic Language of the Quran. Riyadh: Darussalam.

Kais Dukes and Nizar Habash (2010). Morphological Annotation of Quranic Arabic. The Language Resources and Evaluation Conference (LREC 2010).

http://citeseerx.ist.psu.edu/viewdoc/download?doi=10.1.1.180.8039\&rep=rep1\&type=pdf

Leedy, P. \& Ormrod, J. (2001). Practical research: Planning and design (7th ed.). Upper Saddle River, NJ: Merrill Prentice Hall. Thousand Oaks: SAGE Publications.

Maha Alrabiah, Nawal Alhelewh, AbdulMalik Al-Salman \& Eric Atwell (2014). An Empirical Study on The Holy Quran Based On A Large Classical Arabic Corpus. International Journal of Computational Linguistics (IJCL), 5 (1).

Misbah M. D. Al-Sulaimaan \& Amal Y. Muhammed (2006). Meronymy in Arabic: A Semantic Study. Journal of Tikrit University for the Humanities. Tikrit University, 13(2).

Mitra Bokaei Hosseini, Sudarshan Wadkar, Travis D. Breaux, \& Jianwei Niu (2016). Lexical Similarity of Information Type Hypernyms, Meronyms and Synonyms in Privacy Policies. AAAl Fall Symposium on Privacy and Language Technologies 2016. Arlington, Virginia.

Muhammad Luqman Ibnul Hakim Mohd Saad, Muhammad Saiful Anuar Yusoff, Zaitul Azma Zainon Hamzah \& Muhammad Zaidi Zakaria (2017). Leksikal "Sinonim" Dalam AI Quran: Satu Analisis Fungsi Dan Kesan Semantik. Jurnal Linguistik, 21 (1). http://jurnal.plm.org.my/wp-content/uploads/2017/06/4.Leksikal-Sinonim-Dalam-Al-Quran-.pdf

The Quranic Arabic Corpus (n.d). Quran Dictionary. Retrieved from http://corpus.quran.com/qurandictionary Accessed on 9 November 2017.

Wikipedia1 (n.d). بصر.Retrieved from https://ar.wikipedia.org/wiki/بصر Accessed on 9 November 2017.

Wikipedia2 (n.d).عين الإنسان.Retrieved from https://ar.wikipedia.org/wiki/عين_الإنسان Accessed on 20 November 2017

Zahoor Ahmed (2008). Essentials of Arabic Grammar for Learning Quranic Language. Pakistan: Darussalam Publishers \& Distributors.

Zeroual Imad \& Lakhouaja Abdelhak (2014). A New Quranic Corpus rich in Morphological Information. Fiftth International Conference on Arabic Language Processing, CITALA 2014, Oujda, Moroco.

https://www.researchgate.net/publication/280013858 